\title{
Giant lipoleiomyoma-an intimidating entity: case report and literature review
}

\author{
Poojan Agarwal $^{1 *}$, Shubhra Prasad ${ }^{1}$, Devender Singh Chauhan ${ }^{1}$, Adla Satya Narayan Rao ${ }^{2}$
}

${ }^{1}$ Department of Pathology, ${ }^{2}$ Department of Surgery, Post Graduate Institute of Medical Education and Research, Dr. Ram Manohar Lohia Hospital, New Delhi, India

Received: 21 January 2017

Accepted: 28 February 2017

\author{
*Correspondence: \\ Dr. Poojan Agarwal, \\ E-mail: poojanagarwal@gmail.com
}

Copyright: () the author(s), publisher and licensee Medip Academy. This is an open-access article distributed under the terms of the Creative Commons Attribution Non-Commercial License, which permits unrestricted non-commercial use, distribution, and reproduction in any medium, provided the original work is properly cited.

\begin{abstract}
Lipomatous uterine neoplasms are extremely uncommon lesions with a reported incidence of $0.01 \%$ to $0.2 \%$. These lesions frequently pose a diagnostic challenge not only for the clinician but also for radiologists and pathologists alike. Diagnosis requires a multidisciplinary as well as multimodality approach. A 42-year-old peri-menopausal lady presented with abdominal distension, pain and irregular menstrual bleeding. On radiology, an intra-abdodominal hetergenous mass was seen suggestive of neoplastic etiology, possibly intraperitoneal liposarcoma. Microscopy revealed numerous adipocyte clusters intersecting the smooth muscle bundles, diagnostic of lipoleiomyoma. The present case is unusual as the patient had both intramural and broad ligament lipoleiomyoma. Through the present case we revisit clinical and morphological findings of lipoleiomyomas along with review of cases published in literature till date.
\end{abstract}

Keywords: Intraperitoneal, Leiomyoma, Lipoleiomyoma, Liposarcoma, Perimenopausal, Uterine neoplasm

\section{INTRODUCTION}

Lipoleiomyomas are unusual benign fatty tumors comprising of an admixture of adipose tissue and smooth muscle cells. These tumors are variants of conventional leiomyomas, occurring mostly in peri-menopausal and post- menopausal obese women. An association with metabolic diseases including hyperlipidemia, hypothyroidism, and diabetes mellitus has often been suggested. ${ }^{1}$

Giant lipoleiomyomas are notorious, as they have often misled the diagnostic team and caused apprehension of dealing with a malignant neoplasm. Extensive literature search has revealed only a handful of cases with diagnostic dilemma in diagnosing this known clinical mimicker.

\section{Case Presentation}

A 42-year-old female presented with abdominal pain and distension for over six weeks, several episodes of vomiting for 2 weeks, weakness and easy fatigability. Her menstrual history revealed heavy and irregular periods for the past one year. On per abdomen examination, abdomen was tense, there was no fluid thrill and liver and spleen size could not be assessed. Ultrasound abdomen revealed a large, homogenous mass lesion in the abdomen involving all quadrants. Extent of the lesion could not be made out due to acoustic shadows. A contrast enhanced computed tomography (CECT) of abdomen was done which revealed evidence of a large heterogeneous, lobulated, well defined, thick walled mixed density mass lesion with predominantly fatty and soft tissue/ cystic component measuring approximately $25 \times 20 \times 16 \mathrm{~cm}$ in the peritoneal cavity (Figure 1). 


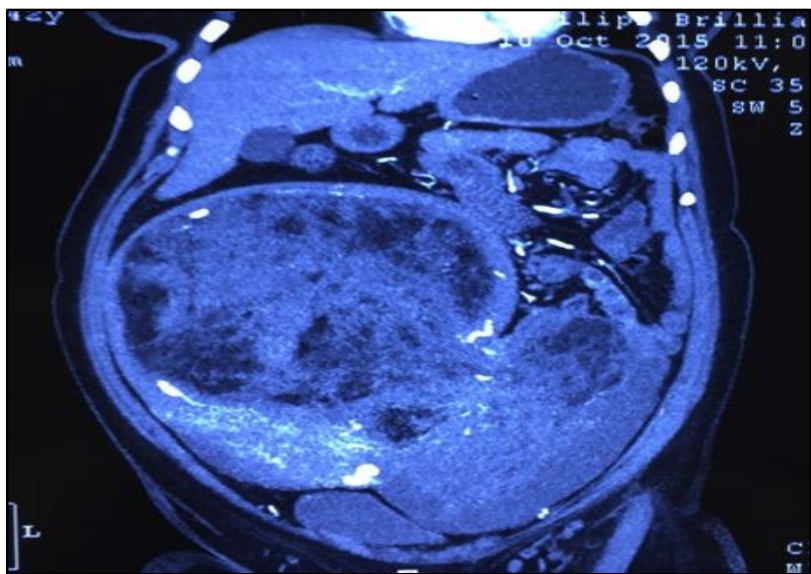

Figure 1: CECT: Heterogeneous thick walled, mixed density mass lesion; extending in sub hepatic region superiorly and displacing the bladder below.

On post contrast images, the mass was multiseptate and heterogeneous enhancement was seen in the periphery of solid portion of the mass. There were no foci of calcification or hemorrhage within the mass. Inferiorly the mass was seen extending into the pelvis and displacing the bladder and uterus to right lateral side. Fat planes between the bladder and uterus appeared maintained. Bilateral ovaries were not visualized separately. Superiorly the mass was seen extending into the sub hepatic region with displacement of bowel loops. Anteriorly the mass was abutting the anterior abdominal wall and posteriorly bilateral psoas muscle. There was no obvious invasion of adjacent organs. Arteriography revealed blood supply of the mass from branches of the left internal iliac artery. A radiological impression of likely Intraperitoneal liposarcoma was given.

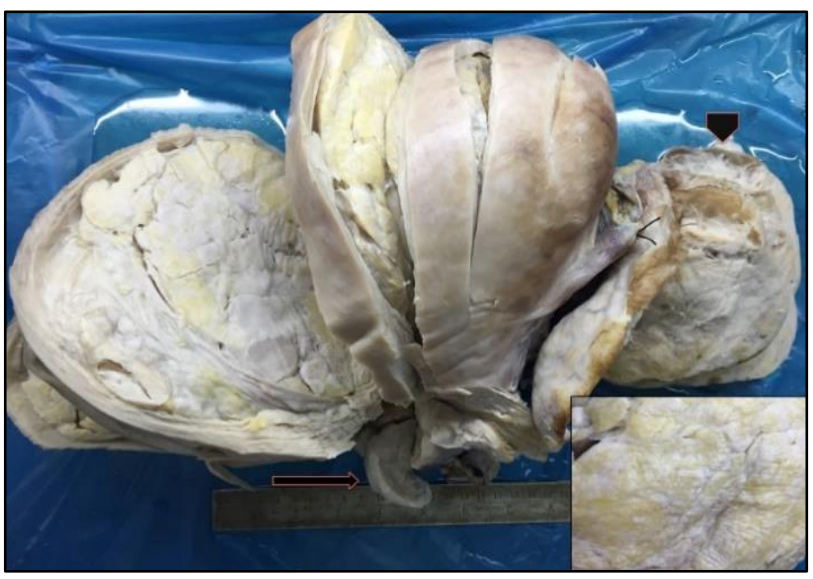

Fig. 2. Gross specimen: Enlarged uterus with distorted endometrial cavity due to intramural mass, submucosal polyp (arrow) and broad ligament mass (arrow head). Cut surface of intramural mass shows admixture of soft fatty and firm white areas (inset).

Routine blood investigations were within normal limits. Serology revealed deranged lipid profile with a low LDL and high triglycerides $(240 \mathrm{mg} / \mathrm{dl})$. A total abdominal hysterectomy with bilateral salpingo-oophorectomy was performed and a $5.8 \mathrm{~kg}$ specimen was sent for histopathology. Gross examination revealed enlarged uterus with endometrial cavity distorted by a large intramural mass measuring 25x20x14 cm (Figure 2).

Another mass was identified in the parametrium measuring $15 \times 15 \mathrm{~cm}$. Cut surface of the intramural and parametrial mass revealed soft (yellow fatty) to firm areas (white whorled). Microscopy showed elongated fascicles of bland, spindle-shaped smooth muscle cells without nuclear atypia with admixed mature adipocytes. Between the muscle cells, a significant amount of fat cells was visible. The adipose component was entirely mature without any lipoblasts, nuclear pleomorphism and prominent mitotic activity (Figure 3, Figure 4).

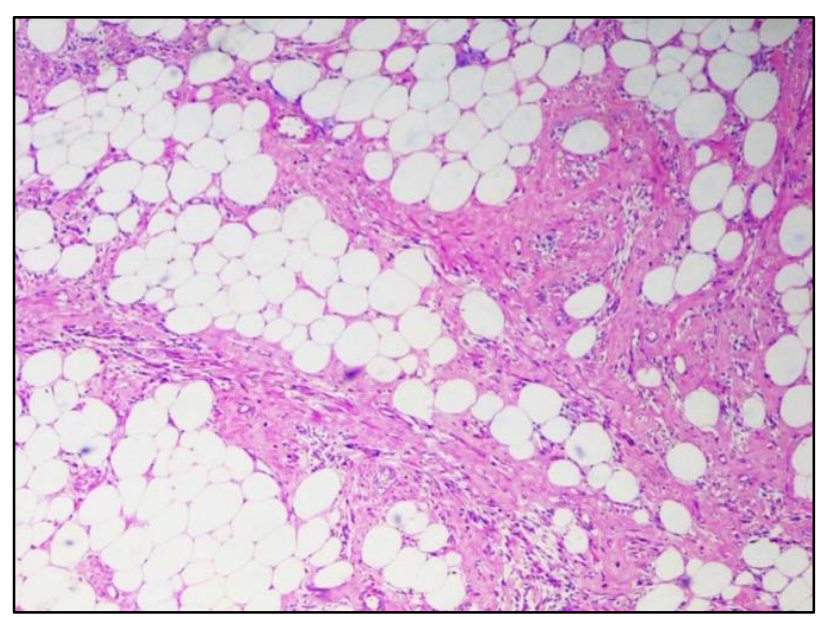

Figure 3: Tumor section showing intermingled adipose tissue and spindle cells $(\mathrm{H}$ and $\mathrm{E}, 100 x)$.

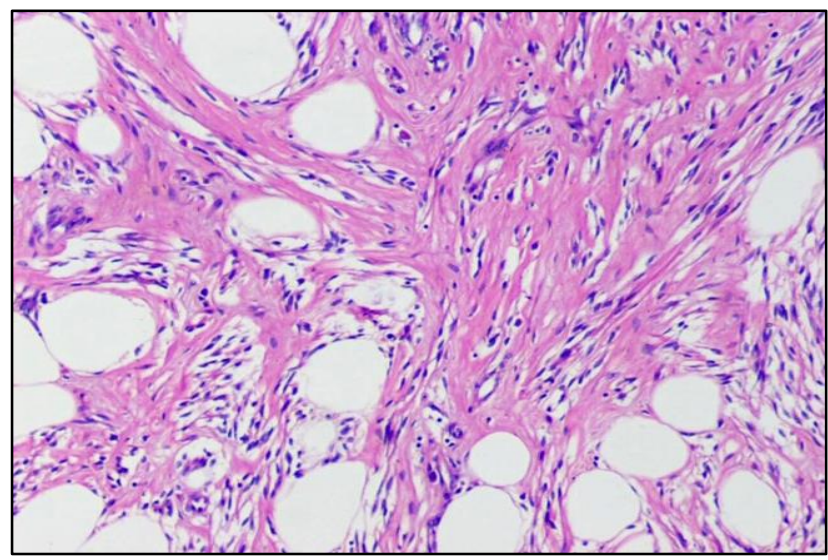

Fig. 4 Adipocytes are seen interspersed in-between bland spindle cell fascicles (H and E, 400x).

Based on the above-described features, a diagnosis of Lipoleiomyoma was made. Another polypoidal sub mucosal growth measuring $6 \times 3 \times 2 \mathrm{~cm}$ was seen arising from the fundus, which on microscopy was, diagnostic of conventional benign leiomyoma. The endometrium was 
in secretory phase while sections from both the ovaries showed surface inclusion cysts with the tubes being unremarkable. The post-operative period of the patient was unremarkable.

\section{DISCUSSION}

Lopstein first described lipoleiomyoma in 1916, but due to poorly understood pathogenesis and features it did not receive much attention. ${ }^{2}$ However, in the recent years, several papers have been published discussing origin and presentation of this unusual entity. ${ }^{3,4}$ Nevertheless, only few reports describe giant lipoleiomyoma.
These giant lesions have been a cause of significant patient morbidity causing abdominal discomfort, distension and dysmenorrhea. Lipoleiomyomas are most commonly located in the uterine corpus, but rarely may be found in other locations, including the cervix, ovary, broad ligament, vulva and retroperitoneum. ${ }^{5}$ Giant lipoleiomyomas often masquerade as malignant neoplasm and occupy a major portion of abdominal cavity making a pre-operative diagnosis extremely difficult. We reviewed cases published in literature of giant lipoleiomyoma measuring $>20 \mathrm{~cm}$ (Table 1). ${ }^{3,6,7}$

Table 1: Review of giant lipoleiomyomas reported in english literature.

\begin{tabular}{|c|c|c|c|c|c|c|c|}
\hline $\begin{array}{l}\text { Author/Ye } \\
\text { ar/No. of } \\
\text { cases }\end{array}$ & $\begin{array}{l}\text { Age/Pari } \\
\text { ty }\end{array}$ & $\begin{array}{l}\text { Presenting } \\
\text { complaint }\end{array}$ & Serology & $\begin{array}{l}\text { Radiological } \\
\text { diagnosis }\end{array}$ & $\begin{array}{l}\text { Tumor size } \\
\text { Weight }\end{array}$ & Location & Associated other neoplasm \\
\hline $\begin{array}{l}\text { Bajaj P et } \\
\mathrm{al}^{4} / 2000 / 1 \\
\text { case }\end{array}$ & $\begin{array}{l}43 \\
\text { years/N } \\
\text { M }\end{array}$ & $\begin{array}{l}\text { Abdominal } \\
\text { distension }\end{array}$ & NM & $\begin{array}{l}\text { USG: Heteroechoic } \\
\text { mass lesion in left } \\
\text { adnexa }\end{array}$ & $\begin{array}{l}25 \mathrm{~cm} \\
\mathrm{WNM}\end{array}$ & Broad Ligament & None \\
\hline $\begin{array}{l}\text { Akubulut } \\
\text { M et } \\
\text { al }^{1} / 2014 / 76 \\
\text { cases }\end{array}$ & $\begin{array}{l}\text { Mean } \\
55.49 \text { yrs } \\
(34-77 \\
\text { yrs })\end{array}$ & $\begin{array}{l}\text { Pelvic pain } \\
\text { <enlarged } \\
\text { uterus } \\
\text { <dysmenorrh } \\
\text { ea }\end{array}$ & $\begin{array}{l}\text { Diabetes } \\
\text { Mellitus (8) } \\
\text { Hypothyroi } \\
\text { dism (6) }\end{array}$ & NM & $\begin{array}{l}>10 \mathrm{~cm} \text { in } 4 \\
\text { cases ** } \\
\text { (Max. } \\
\text { dimension } \\
55 \mathrm{~cm} \text { ) } \\
\text { WNM }\end{array}$ & $\begin{array}{l}\text { Uterine corpus } \\
(90.7 \%- \\
\text { intramural })< \\
\text { cervix }(6.5 \%) \\
\text { <retroperitoneal } \\
(1.3 \%)<\text { broad } \\
\text { ligament }(1.3 \%)\end{array}$ & $\begin{array}{l}\text { Leiomyoma (34), } \\
\text { adenomatoid tumor (2), } \\
\text { endometrial carcinoma (1), } \\
\text { endometrial carcinosarcoma } \\
\text { (1), Ovarian: teratoma (1), } \\
\text { fibrothecoma (2), serous } \\
\text { cystadenofibroma (4), serous } \\
\text { carcinoma (3), Carcinoma: } \\
\text { breast (1), gastric (1), rectum } \\
\text { (1) }\end{array}$ \\
\hline $\begin{array}{l}\text { Karaman E } \\
\text { et } \mathrm{al}^{2} / 2015 / \\
1 \text { case }\end{array}$ & $\begin{array}{l}45 \text { years/ } \\
\text { Multipar } \\
\text { ous }\end{array}$ & $\begin{array}{l}\text { Lower } \\
\text { abdominal } \\
\text { pain and } \\
\text { distension }\end{array}$ & $\begin{array}{l}\text { Hyperchole } \\
\text { sterolemi, } \\
\text { Type II } \\
\text { diabetes } \\
\text { mellitus, } \\
\text { raised CA- } \\
125 \text { levels }\end{array}$ & $\begin{array}{l}\text { TVS-USG: Solid } \\
\text { complex mass in } \\
\text { pelvis extending to } \\
\text { sub diaphragmatic } \\
\text { area MRI: solid } \\
\text { mass with cystic and } \\
\text { fatty component; } \\
\text { Leiomyosarcoma }\end{array}$ & $\begin{array}{l}32 \mathrm{~cm} \\
\text { WNM }\end{array}$ & Subserosal & None \\
\hline $\begin{array}{l}\text { Present } \\
\text { case/ 2016/ } \\
1 \text { case }\end{array}$ & $\begin{array}{l}42 \\
\text { years/G4 } \\
\text { P3 }\end{array}$ & $\begin{array}{l}\text { Abdominal } \\
\text { pain, } \\
\text { distension, } \\
\text { vomiting and } \\
\text { weakness }\end{array}$ & $\begin{array}{l}\text { Deranged } \\
\text { lipid profile }\end{array}$ & $\begin{array}{l}\text { USG: Homogenous } \\
\text { mass lesion } \\
\text { CT: Intraperitoneal } \\
\text { liposarcoma }\end{array}$ & $\begin{array}{l}25 \mathrm{~cm} \\
5.8 \mathrm{~kg}\end{array}$ & Intramural & $\begin{array}{l}\text { Broad ligament } \\
\text { lipoleiomyoma }\end{array}$ \\
\hline
\end{tabular}

Lower abdominal pain was most common presenting complaint in these patients followed by abdominal distension. Pre-operative scans in the largest reported tumor were suggestive of a malignant mass lesion, as was also observed in the present case. Large size of the mass and heterogeneous nature, together with compression of the surrounding viscera often give a false impression of mitotically active lesion on radiology. ${ }^{7}$

Origin of lipoleiomyomas has been a subject of much controversy and speculation. Few reports have attributed the pathogenesis to divergent differentiation of uterine smooth muscles towards adipocytes; a theory supported by expression of ER, PR and $\mathrm{Ki}-67$ in fat cells of lipoleiomyoma. ${ }^{3,8}$ Another theory of adipocyte metaplasia of uterine smooth muscles is favored by reactivity of adipocytes in between smooth muscle cells for vimentin and desmin. These tumors also show t $(12 ; 14)$, a feature observed in conventional leiomyomas. ${ }^{5}$

Several authors have observed a frequent occurrence of metabolic disorders like hyperlipidemia, hyperthyroidism and diabetes mellitus along with lipoleiomyoma. ${ }^{7}$ Lin and Hanai in their study highlighted role of several lipid and non-lipid mechanisms along with a complex interplay of altered hormonal profile at menopause to have a pivotal role in development of lipomatous changes in leiomyoma. ${ }^{8}$ Most cases of lipoleiomyomas are in females of post or perimenopausal age while conventional leiomyomas are known to occur in women of reproductive age group and regress after menopause. A possible reason for this other than that stated above could 
be a microscopic variation in lipomatous component, which is often underreported in convention leiomyomas as these lesions are benign and one tends to overlook minor variations. Akubulut et al in their review of conventional leiomyomas, found $46.05 \%$ (35 out of 76 cases) of patients had minimal lipomatous change, concentrated in focal areas only. ${ }^{3}$ The differential diagnoses of uterine tumours with adipose tissue and spindle cells include spindle cell lipoma, angiolipoma, fibrolipoma and myolipoma. A meticulous review of histomorphology can help in differentiating these lesions. Lipoleiomyoma is benign, however occasional case report of benign metastasizing lipoleiomyomatosis and sarcomatous transformation has been described, thus warranting a close follow-up. ${ }^{9,10}$

\section{CONCLUSION}

Lipoleiomyomas are extremely rare uterine wall tumors and a co-existent similar lesion in broad ligament is even rarer. These lesions have gained notoriety in the recent years because of their unusual presentation, significant patient morbidity and frequent misdiagnosis as a malignant neoplasm on clinico-radiological grounds. To avoid undue intervention in patients for the management of this benign neoplasm, one needs to be aware of the varied facets of this lesion.

\section{ACKNOWLEDGEMENTS}

Author would like to thank the contribution of Mrs. Renu, Mrs. Hema and Mr. Anant who provided technical help in tissue processing and staining.

Funding: No funding sources Conflict of interest: None declared

Ethical approval: Not required

\section{REFERENCES}

1. M. Lin, Hanai J. Atypical lipoleiomyoma of the uterus. Acta Pathologica Japonica. 1991;41(2):164-9.

2. Willen R, Gad A, Willen H. Lipomatous lesions of the uterus. Virchows Arch A Pathol Anat Histopathol. 1978;377:351-61.

3. Akbulut M, Gundogan M, Yorukoglu A. Clinical and Pathological Features of Lipoleiomyoma of the Uterine Corpus: A Review of 76 Cases. Balkan Med. J. 2014;31(3): 224-9.

4. Wang X, Kumar D, Seidman JD. Uterine lipoleiomyomas: A clinicopatho- logic study of 50 cases. Int J Gynecol Pathol. 2006;25:239-42.

5. Hu J, Surti U, Tobon H. Cytogenetic analysis of a uterine lipoleiomyoma. Cancer Genet Cytogenet. 1992;62:200-2.

6. Bajaj P, Kumar G, Agarwal K. Lipoleiomyoma of broad ligament: a case report. Indian $\mathrm{J}$ Pathol Microbiol. 2000;43(4):457-8.

7. Karaman E, Cim N, Bulut G, Elci G, Andic E, Tekin $\mathrm{M}$, et al. A Case of Giant Uterine Lipoleiomyoma Simulating Malignancy. Case Reports in Obstetrics and Gynecology. 2015;4.

8. Terda T. Giant subserosal lipoleiomyoma of the uterine cervix and corpus: A report of 2 cases. Appl Immunohistochem Mol Morphol. 2015;23(2):1-3.

9. Fukunaga, Masaharu. Benign "Metastasizing" Lipoleiomyoma of the Uterus. International Journal of Gynecological Pathology. 2003;22(2):202-4.

10. McDonald AG, Dal Cin P, Ganguly A, Campbell S, Imai Y, Rosenberg AE, et al. Liposarcoma arising in uterine lipoleiomyoma: a report of 3 cases and review of the literature. Am J Surg Pathol. 2011;35(2):221-7.

Cite this article as: Agarwal P, Prasad S, Chauhan DS, Rao ASN. Giant lipoleiomyoma-an intimidating entity: case report and literature review. Int J Reprod Contracept Obstet Gynecol 2017;6:1660-3. 